\title{
Entrepreneurship, University Research, and Growth: European North vs. South
}

\author{
Panagiotis E. Petrakis \\ National and Kapodistrian University of Athens (Economic Department), Athens,
}

Greece

\section{Introduction}

The problem that this chapter tries to solve, is to find the relation between entrepreneurship, university research, and economic growth. The contribution of the present analysis is that, we aim to underline a) the role of university entrepreneurship in economic growth, b) to identify the reasons why this role is underdeveloped in the European South compared to the European North and c) to suggest certain policy measures to exploit university entrepreneurship. More specifically, we propose that the theoretical background of university entrepreneurship is affected by five sectors. The first refers to the entrepreneurship opportunity theory. The second refers to the economies of information and the asymmetric information issues in relation to the transaction costs theory. Additionally it includes the principal agent theory, which provides some considerations on the moral hazard problems of the academics. The third includes the network theory as a part of the social capital theory referring to the terms of academic entrepreneurship activation. The fourth refers to the property rights theory, which can determine the procedures for the transformation of knowledge. Finally, the cultural theoritization could give some lights on the cultural background of university entrepreneurship development. Unfortunately, there are no reliable aggregate data portraying some form of activity for university entrepreneurship. This is why the empirical part of this chapter will cover the entire issue in three stages. Initially, we analyze the relation between the educational system and research activity, then the relation of research activity and research results and finally the relation of research results and academic spin offs. Next, we discuss the relationship between Academic Spin Offs and entrepreneurship. The case study used in the analysis is the comparison of the European South and North, so as to also create empirical images on the issues covered by this chapter.

The order of the chapter is as follows. Section 2, examines the theoretical background and the connection between entrepreneurship, university research, and economic growth and compares the patterns of activity of university entrepreneurship in the European South in relation to the European North. Section 3, presents five sectors that affect the theoretical background of university entrepreneurship. Next, Section 4 analyses that education system and academic research lead to research results that can contribute to the growth of academic entrepreneurship, through the creation of spin off companies, while Section 5 discusses the relationship between Academic Spin Offs and entrepreneurship. Finally, Section 6 presents 
the conclusions, through a complete interpretation of the European South lag in comparison to the European North, suggesting specific policy measures.

\section{Entrepreneurship, economic growth, and university research}

Porter (2002) determined three stages for the growth of economies: a) the factor-driven stage, b) the efficiency-driven stage and c) the innovation-driven stage. The first stage (factor-driven stage) is characterized by the fact that countries in this stage compete through low-cost efficiency in product production or produce low added value products. This stage does not create the appropriate conditions for innovation growth and increase of exports. In the next stage (efficiency-driven stage), economies increase production efficiency and the educational level of their workforce. In the efficiency-driven stage, economies have efficient production practices, to be able to exploit economies of scale. Self-employment rates drop, while capital, work and technology seem to play the key role in productiveness. The transition to the next stage (innovation-driven stage) is noted by entrepreneurial activity based on human capital.

Academic entrepreneurship plays a role in both the efficiency-driven and the innovationdriven stages. In the first, because production of research results and their exploitation contributes to the improvement of efficiency, and in the second, because, of course, it produces innovations.

Thus, academic activity contributes to the growth of the economy while spin offs form the basic source of innovation creation and exploitation contributing to growth and employment (Audretsch et al., 2006). Indeed, the promotion of academic research forms the basic source of enhancement of entrepreneurial environment as it is based on the networking between the university community and the public and private sectors (OECD, 2000).

The growth of the entrepreneurial sector is not only dependant on its particular features (such as size, age, geographical location, etc.) but also on the rate of knowledge sharing from universities as access to knowledge affects the growth of companies (Audretsch and Lehmann, 2005).

Examining the contribution of universities to economic growth, Breznitz et al. (2008) stressed the process of technology transfer and its impact on growth. It seems that the production of new knowledge by universities has a positive impact on the growth of businesses as they are able to absorb knowledge and, finally, investments in research activities have a positive effect in business growth (Cassia \& Colombelli, 2008).

\section{The theoretical background of university entrepreneurship}

Five theoretical fields offer the infrastructure for the study of academic entrepreneurship. These are the entrepreneurial opportunity theories, the economics of production of information, the networks theory as part of the social capital, the property rights and the social dimensions of the cultural background.

\subsection{Entrepreneurial opportunity theories}

The recognition of entrepreneurial opportunities and the decision for their commercialization leads to the creation of new businesses. Entrepreneurship may contribute 
to economic growth as a mechanism connecting the channel of knowledge sharing with economic growth (Audretsch et al., 2006).

Entrepreneurial opportunities are situations by which products, services, raw material and production methods are harmonically combined, introduced to the market and sold, bringing more revenue than their production cost. They do not refer only to the creation of new products and services, but also to the better exploitation and the combination of existing resources, in order to produce a better product than the one covering a given need of the market. Therefore, the need of the market is crucial in the given definition of entrepreneurial opportunity. It is thus necessary for the entrepreneur to be able to realise and predict where the need is at any given time in the market for a new or sufficiently differentiated product. The spread of innovations within the economy and technological inconsistencies create entrepreneurial opportunities.

Yet, do all opportunities have the same potential of affecting economic activity? Obviously not. Thus, there are entrepreneurial "multivalent" opportunities and simple entrepreneurial opportunities. The latter do not include the potential for the creation of new entrepreneurial opportunities and therefore their social significance is limited. Of course, finally, profitmaking from the exploitation of entrepreneurial opportunities is what urges to their search and discovery (Kirzner, 1973).

The theory of the existence and identification of entrepreneurial opportunities is mainly based on three schools of thought. Shane \& Venkataraman (2000) representing the economic school claim that entrepreneurial opportunity is an objective phenomenon existent in time and space although not all may know of it. In essence it claims that opportunities do exist and wait to be identified by someone (Kirzner, 1973), attributing entrepreneurial opportunities to the allocation of information as to material opportunities existent in society. Based on the economic school, entrepreneurial opportunities offer a clear advantage to the first person to discover them (Lieberman \& Montgomery, 1988). Furthermore, the economic school accepts that differences in economic information are crucial for the existence of entrepreneurial opportunities.

The cultural school claims that entrepreneurial opportunities are subjective and not objective creations-phenomena. According to Weick (1979), entrepreneurial opportunities exist as long as people understand their existence. Therefore, entrepreneurial opportunities do not objectively exist, waiting to be discovered. Protagonists - individuals - create them combining shapes and cognitive organizations to develop them. Thus, the existence of a particular cultural background forms the base for a maintainable competitive advantage (Pollock \& Rindova, 2003).

Finally, the socio-political school is a combination of the previous two, stressing the significant role of administrative mechanisms in determining entrepreneurial opportunities (Granovetter, 1985). In agreement with the economic school, it underlines the objective properties of entrepreneurial opportunities, stressing the objective properties of entrepreneurial opportunities. It deems that entrepreneurial opportunities exist and grow within complex networks of social relations that shape economic activity. In that sense, it emphasises networks rather than resources (Aldrich \& Fiol, 1994; Thornton, 1999). In these networks, social protagonists must activate resources in order to exploit objective opportunities. Within the socio-economic networks, structural opportunities available to the 
protagonists are indicated. Therefore, the position that one has in the networks has a key role in whether he/she will be able to discover opportunities. The positioning of protagonists in a particular network determines the volume of the crucial resources and information that the protagonist may have in order to exploit opportunities (Burt, 1992).

In order to exploit the results of their research, scientists need to identify and understand market needs (Scholten, 2006). Vohora et al. (2004) stress that identification of opportunities plays an important role in the growth stage of a spin off company. Many studies have shown that experience (Shane \& Venkataraman, 2000), social funding (Shane and Stuart, 2002) and information (Fiet, 1996), are contributing factors in identification of entrepreneurial opportunities.

The identification process of an entrepreneurial opportunity, in an academic environment, includes two stages. The first includes the identification of an idea that may evolve in an opportunity (Singh et al., 1999). This idea originates from new knowledge produced in the framework of academic research. The next stage includes the assessment of the idea, namely the identification of an opportunity through data accumulation on the market (Elfring \& Hulsink, 2003).

Many researchers have also claimed that an important drawback in the commercialization of university research is the fear that businesses do not wish the spread and free exchange of scientific findings as they prefer their own exploitation and not their free spreading (Chakrabarti, 2003).

The above analysis shows that academic entrepreneurial activity is a process that might be deemed as included in the logic of the socio-political school on production of entrepreneurial opportunities and draws elements from almost all schools of thought. It is based mainly on asymmetric information and the advantage of priority of identification in entrepreneurial opportunities (economic school), while, in essence, its protagonists create it from scratch in the sense that opportunities do not exist just to be discovered but are "created". In this context, the cultural background plays a definitive role in the determination of entrepreneurial opportunities (cultural school). Yet, above all, processes and co-operation and information networks (socio-political school) play the definitive role in the growth of academic entrepreneurship. In the USA, entrepreneurial potential has always been produced through scientific research. However, the Bayh Dole law had to be created in the 90's, for academic entrepreneurship to grow.

Table 1 presents the "opportunity entrepreneurship" variable which is calculated as the rate of people 18-64 years old who are either aspiring entrepreneurs or owners - managers of new businesses, who state that a) they are driven by opportunity and not by need, and b) the driving force is independence and revenue growth rather than its stability. The data of Table 1 show clearly that budding or active entrepreneurs are proportionately more in the European North than in the European South.

\subsection{The economics of university production of information}

In the framework of academic entrepreneurship, asymmetrical information creates three issues: 


\begin{tabular}{|l|c|}
\hline Country & $\begin{array}{c}\text { Opportunity } \\
\text { entrepreneurship }\end{array}$ \\
\hline Denmark & 0.89 \\
\hline Ireland & 0.80 \\
\hline Netherlands & 0.88 \\
\hline Sweden & 0.85 \\
\hline Finland & 0.80 \\
\hline Greece & 0.70 \\
\hline Spain & 0.80 \\
\hline Italy & 0.75 \\
\hline Portugal & 0.72 \\
\hline
\end{tabular}

Source: Global Entrepreneurship Monitor (GEM).

Table 1. Opportunity entrepreneurship (2001-2006)

Moral hazard problem: It appears when contracting parties avoid the process of technologyknowledge sharing, as they do not have all the necessary information available (Arora, 1996). Lowe (2002) realizes that asymmetrical information between the inventor and a private company increases licensing costs on the side of the business. He also notes that there are two forms of asymmetrical information, that of technological uncertainty and that of implied knowledge, which affect the funding potential for an invention of the academic community. Businesses that are founded to exploit university inventions may secure their sustainability by patenting the knowledge they produce so as to compete with already existing businesses (Nerkar \& Shane, 2003). Uneven distribution of information is what leads to the creation of spin offs, providing then with a competitive advantage.

Adverse selection: It appears when sellers of low quality inventions present their inventions as high quality. The buyer in this case is at an adverse position, as he/she does not have all the necessary information available (Anton \& Yao, 1994).

Hold-up: It occurs when the contracting parties of the transaction speculatively renegotiate the terms of the agreement to their benefit (Pisano, 1989).

Spin offs may have cost advantages due to the knowledge held by the researcher, resulting in limited transaction costs and information problems (Shane, 2002). Particularly, Shane (2002) showed that licensing to researchers is more effective, when the patents are ineffective in preventing information problems (such as moral hazard and adverse selection). This happens because the analyst's knowledge does not allow such problems in new businesses.

During knowledge transfer, asymmetrical information between buyer and seller on the value of the innovation may be observed. Buyers usually cannot evaluate the quality of the patents in advance, while it may be difficult for researchers to assess the potential commercial profit making of their inventions (Macho-Stadler et al., 2007). When drafting a contract with an academic spin off, factors such as the problem of the researcher's moral hazard, participation limitations of key researchers and the issue of asymmetrical information are important. Furthermore, when the moral hazard problem is pronounced, the need for the researcher's economic participation in the spin off leads to further ineffectiveness. Copyright and shares are 
important means for dealing with moral hazard, participation limitations, as well as asymmetrical information problems (Macho-Stadler et al., 2008)

Moreover spin offs alter the information environment of businesses. Transaction costs and the impact on the prices of transactions are also higher. Indeed alterations in the information environment benefit more the parties who have the advantage in obtaining information (Huson \& MacKinnon, 2003). Ultimately, the transaction uncertainty resulting from asymmetrical information gives an uncertainty premium to transaction costs. This situation increases risk in the economy by discouraging people from undertaking large-scale investment plans and encouraging smaller business ventures instead.

The general characteristics of the transaction cost theory, including the major concepts such as uncertainty, frequency and asset specificity, and the human aspects such as bounded rationality and opportunism, constitute components and factors that deeply affect the active cultural background in every society. Uncertainty avoidance deals with a society's tolerance for uncertainty and ambiguity, indicating to what extent a society programs its members to feel either uncomfortable or comfortable in unstructured situations. Southern European cultures seem to have lower uncertainty avoidance in comparison with the southern. Southern cultures are not to keen on uncertainty and try to reduce their risks to the minimum by introducing strict laws and rules, safety and security measures. As a result, entrepreneurship and innovation are mostly promoted in countries of low uncertainty avoidance (Herbig \& Dunphy, 1998). Furthermore, as the needed transactions increase in an economy, so does the possibility of corruption (corruption perception index). The following table presents the corruption perceptions index, which is a snapshot of perceptions of public sector corruption. It uses the counter-variable, so the prices it can assume are between 0 (highly corrupt) and 10 (highly clean). This index demonstrates a clear indication on the difference between South and North countries. North countries rank top positions while, the South rank low.

\begin{tabular}{|l|c|c|c|}
\hline Country & $\begin{array}{c}\text { Starting a } \\
\text { business }^{1}\end{array}$ & $\begin{array}{c}\text { Uncertainty } \\
\text { Avoidance }^{2}\end{array}$ & $\begin{array}{c}\text { Corruption } \\
\text { Perceptions }^{\text {Index }}\end{array}$ \\
\hline Denmark & 6 & 23 & 9.4 \\
\hline Ireland & 14 & 35 & 7.7 \\
\hline Netherlands & 10.2 & 53 & 8.9 \\
\hline Sweden & 15 & 29 & 9.2 \\
\hline Finland & 14 & 59 & 9.2 \\
\hline Greece & 30.4 & 112 & 4.2 \\
\hline Spain & 47 & 86 & 6.4 \\
\hline Italy & 11.8 & 75 & 4.6 \\
\hline Portugal & 16.2 & 104 & 6.2 \\
\hline
\end{tabular}

Source: Doing business Reports, The World Bank Groups, Hofstede (1980), Transparency International. Notes: ${ }^{1}$ Time is recorded in calendar days. This measure captures the median duration that incorporation lawyers indicate is necessary to complete a procedure with a minimum follow-up with government agencies and no extra payments. Average for the period 2006-2010.

${ }^{2}$ Hofstede (1980).

${ }^{3}$ Average for the period 2006-2010.

Table 2. Characteristics of transactions in societies 
Another significant index of high transaction costs in an economy is the time needed to start a business. Similar indicators can be calculated for a number of actions regarding entrepreneurial creativity in a particular external environment. The increase of a business' start or end time is likely to be a barrier to entrepreneurship opportunity. The following table presents the days needed in each country to start up a business. It is observed that North countries remain stably at low levels during the five-year period. In particular, 12 days in average are needed in Northern countries while in Southern countries the double are needed, although as years go by we note some improvement, particularly in Portugal.

\subsection{The network and social capital aspects}

In the previous part, we realized that the discovery of entrepreneurial opportunities depends on the information distribution process in society. Networks significantly contribute to such information (Granovetter, 1985).

The relevant literature stresses the importance of the creation of networks within the university community (Ring \& Van de Ven, 1994, Nicolaou \& Birley, 2003a, Shane, 2004). When establishing a spin off, obviously the original ties originate from the interpersonal relations of the researchers with members of the academic community. Yet their expansion towards the industrial and economic sector is necessary, in order to escape the narrow limits of an academic business (Vohora et al., 2004, Bekkers et al., 2006).

To secure the successful course of a researcher participating in a spin off company, he must attempt to integrate in networks. Indeed, researcher entrepreneurs do not have common characteristics with the lone Schumpeterian entrepreneur (Mustar, 1997). Academic entrepreneurs have minimum heterogeneity amongst them than other entrepreneur groups. This is a group with clear characteristics and limited entrepreneurial experience. In this framework, Nicolaou \& Birley (2003b) stress the importance of networks, particularly as regards technology transfer through an organized network. They further note the importance of network organization by universities for the promotion of the technology that they produce.

Over the past years, the collaboration rate between institutions of most countries has increased. This fact is shown by the co-authorship and co-invention existent in scientific publications and in patents. Generally, there is a positive correlation between rates for international scientific collaboration and the applications for patents in all countries, which indicates the existence of common factors that urge research and the creation of patents. Smaller countries tend to have higher rates of international collaboration, something that justifies the need for search of opportunities of this kind (OECD, 2011).

On the issue of network development, Burg et al. (2008) stress that there are two phases in developing academic spin-offs. Originally, the existence of the appropriate infrastructure is required, which includes a collaboration network of investors, administrators and consultants. Then this network allows the support of separate entrepreneurial ventures (Burg et al., 2008).

Nicolaou \& Birley (2003b) analyze the benefits and consequences of social networks on spin offs. The academic inventor is at an advantageous position as he identifies specialized parts of the market and can adjust his invention accordingly. Furthermore, he has immediate 
access to information and sources while in the same time through his contacts with businesses, he may acquire market information in time, resulting in an enhancement of $R \& D$. Moreover, references play a significant role in the entrepreneurial ventures of researchers. Thus venture capitalists and businesses are more likely to invest on spin offs which they know or have received positive references as in this way they also limit the issue of asymmetrical information (Shane \& Stuart, 2002). Specifically, studying the importance of networks in spin off companies of the Massachusetts Institute of Technology (MIT), Shane \& Stuart (2002) showed that owners who had direct and indirect relations with the venture capital companies are more likely to be funded and sustainable.

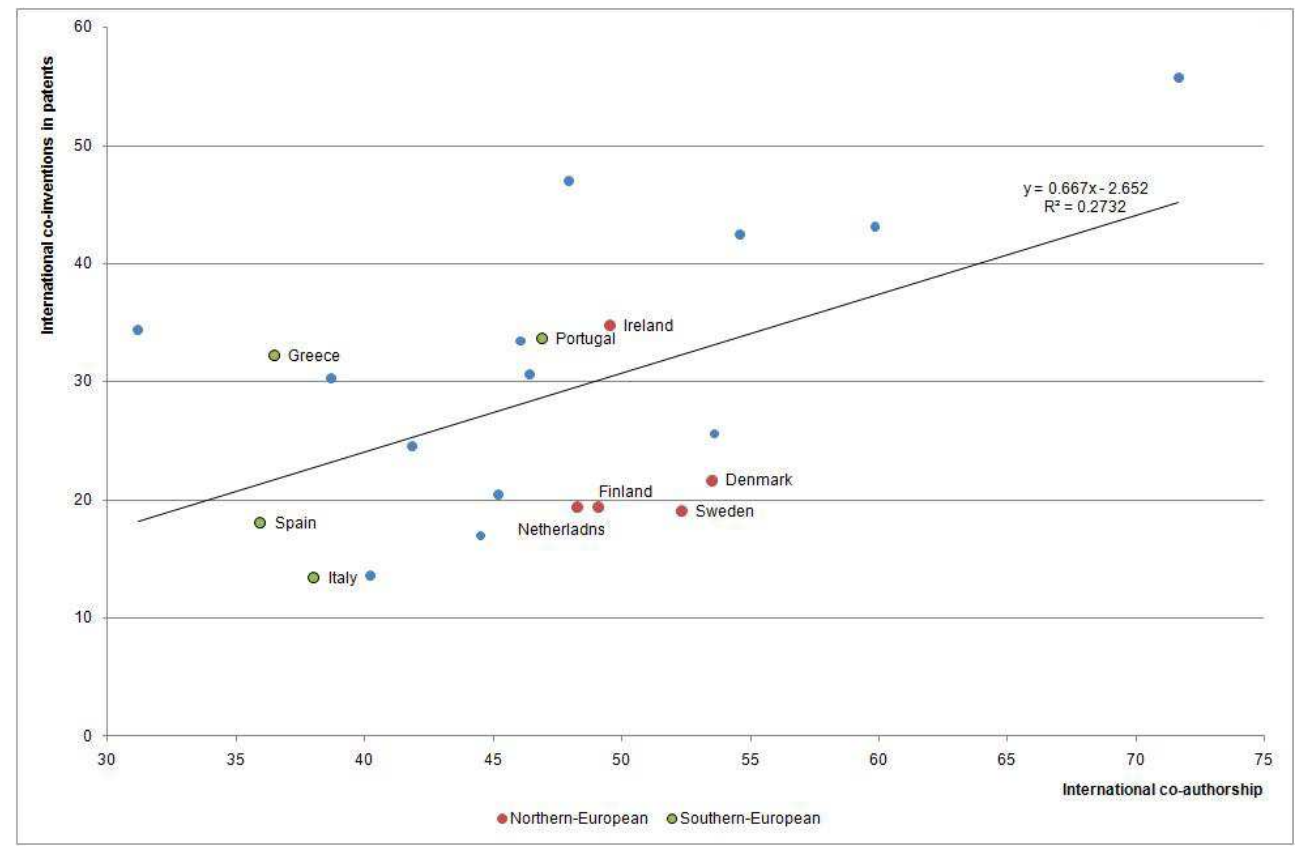

Source: OECD, Science, Technology And Industry Scoreboard, 2011

Note: International co-authorship of scientific publications is based on the share of articles with authors affiliated with foreign institutions in total articles produced by domestic institutions. Co-inventions are measured as the share of patent applications with at least one co-inventor located abroad in total patents invented domestically.

Fig. 1. International collaboration in science and innovation

Various factors have a significant impact on the operation and performance of a spin off company. Connections with financial institutions have multiple impacts on the technological potential and the finding of the economic resources invested on a start-up company (Lee et al., 2001). Furthermore, individuals belonging to an entrepreneurial network are more likely to identify opportunities than individuals who are independently active (Singh et al., 1999, Lee et al., 2001).

The networks of spin off companies are linked to social capital theory (Scholten, 2006). The key dimensions of social capital are networks in which it is integrated, as well as the 
necessary trust for their sustainability. Networks can be classified into personal and broader social networks. According to this theory, external networks of a business are a significant source for the performance and growth of a company (Gabbay \& Leenders, 1999).

Social capital refers to the benefits enhanced by participation and inclusion of individuals in social networks (Portes, 1998). Bourdieu (1986) defined it as the total of real and potential resources related to one being a member of a stable network of mutual familiarization. Putnam (1995) deems as social capital the characteristics of a social organization that "facilitate the coordination and collaboration to a common benefit". Those characteristics include three concepts: networks, rules and trust.

Trust is the second key dimension of social capital. The two basic forms of trust that are mostly related to social capital are the interpersonal trust and institutional trust (Cox, 2003). Both forms make it possible to expand and spread relations integrating social capital.

Table 3 shows the proportion of people who think that most people can be trusted according to the question: "generally speaking, would you say that most people can be trusted or that you need to be very careful in dealing with people?" There is an evident difference between Northern and Southern European countries, since this index is higher for Northern than Southern ones.

\begin{tabular}{|l|c|}
\hline Country & $\begin{array}{l}\text { Most people can } \\
\text { be trusted }\end{array}$ \\
\hline Denmark & $66.50 \% *$ \\
\hline Ireland & $35.80 \% *$ \\
\hline Netherlands & $45.00 \%$ \\
\hline Sweden & $68.00 \%$ \\
\hline Finland & $58.90 \%$ \\
\hline Greece & $23.70 \% *$ \\
\hline Spain & $20.00 \%$ \\
\hline Italy & $29.20 \%$ \\
\hline Portugal & $10.00 \% *$ \\
\hline
\end{tabular}

Source: Values Survey Databank, 2005 - 2008.

Note: * Available data from previous survey (1999)

Table 3. Generalised interpersonal trust

\subsection{Property rights considerations}

Institutions, as the "rules of the game" in a society (North, 1990), are defined as society's collective choices. They usually express conflicts of interest and develop under the influence of history and cultural background. Generally, favourable economic institutions (with regard to entrepreneurship) are those that offer secure property rights in a wide range of social activities (Acemoglu et al., 2004). The relationship between institutions and entrepreneurship stems from three different sources, which are the following: a) their contribution to coordination and governance, $b$ ) their influence on the process of knowledge development and c) their effect on income distribution and the development of social coherence (Easterly et al., 2006). The main tools of economic institutions are property rights and contractual conditions. 
The protection of property rights seems to be a fundamental part of economic growth (North, 1981; Rosenberg and Birdzell, 1986; Rodrik et al., 2004; Acemoglu \& Johnson, 2005). Subsequently, entrepreneurship thrives through secure property rights which can be used in voluntary contract-based exchanges.

A high value for the property rights variable (as presented in Table 4) indicates that a country's laws protect private property rights, the government enforces those laws, the judiciary is independent, there is no corruption and it is easy to enforce contracts. These conditions are expected to encourage the foundation of new businesses. Northern countries have again higher rates (average of 90.6) than Southern.

\begin{tabular}{|l|c|}
\hline Country & $\begin{array}{c}\text { Property } \\
\text { rights* }\end{array}$ \\
\hline Denmark & 91 \\
\hline Ireland & 90 \\
\hline Netherlands & 90 \\
\hline Sweden & 91 \\
\hline Finland & 91 \\
\hline Greece & 52 \\
\hline Spain & 70 \\
\hline Italy & 51 \\
\hline Portugal & 70 \\
\hline
\end{tabular}

Source: The Heritage Foundation, Index of Economic Freedom (HER).

Note: * An assessment of the ability of individuals to accumulate private property, secured by clear laws that are fully enforced by the state. It is the mean for the period of $2006-2010$.

Table 4. Property rights

A successful mean of intervention in the property rights regime is the law that changed their operational framework in the USA. The Bayh-Dole Patent and Trademark Amendments Act of 1980 is a US law on copyright (intellectual property) arising from funded research. Inter alia, it granted US universities, small businesses and non profit organizations the control of copyright on their inventions but also the copyright arising from public funding.

\subsection{The cultural background aspect}

The definition of entrepreneurial opportunities raises the question of the exact impact of culture on entrepreneurship, as indicated by disciplines such as economics (Schumpeter, 1934), sociology (Weber, 1930) and psychology (McClelland, 1961). Moreover, it involves several issues attributed to the social characteristics that constitute what we understand as "culture". "Culture is defined as a set of shared values, beliefs, and expected behaviours" (Hayton et al., 2002). The cultural characteristics of societies reflect psychological social stereotypes created over time, which are prior human constructs to the current conditions of transactions and institutions. The cultural background can be considered an endogenous product of human civilisation (Hong, 2009; Oyserman \& Sorensen, 2009) consisting of cultural syndromes that can be considered as intermediate mental constructions that originate from the distant past, connecting it with the present (Hong, 2009). This view is in 
line with cultural evolutionary theory, which stresses that individuals tend to adopt certain pre-existing cultural values (Bergh \& Stagl, 2003).

McClelland (1961) attempted to relate societal values with entrepreneurial variables and economic dynamism in general. Furthermore, he attempted to quantify the impact of entrepreneurship culture in economic development without using an economic model. Lynn (1991), also without using a model, concluded that countries moving towards competing values are associated with higher levels of economic development. Scientific research also highlights other factors (Triandis, 2009), including cultural complexity, cultural austerity (Triandis, 1994) and value orientation theory (Kluckhohn \& Strodtbeck, 1961). The different social and political procedures that shape the cultural background of each society guide human behaviour and the character of all of the stakeholders. Thus, Grief (1994) highlights the fact that different cultural values lead to different societal structures of economic relationships.

Many studies have quantified the "effects" of the cultural background and provided relevant data for a large number of countries (McClelland, 1961; Hofstede, 1980, 2001; House et al., 2004; Saving \& Schwartz, 2007). Georgas and Berry (1995) and Inglehart (1997) have identified groups of countries that seem to share common cultural values. Cultural and institutional factors may explain cross-national differences in levels of entrepreneurial activity (Wennekers et al., 2002, Wennekers, 2005). Thomas and Meller (2000) found that differences in cultural orientation between countries affect the personality characteristics commonly associated with motivation for entrepreneurship. Furthermore, studying regional differences of entrepreneurial culture in Sweden using cultural values and belief data, Davidsson \& Wiklund (1997) concluded that there is a weak relationship between entrepreneurial values and the formation of new regional new firms.

Shane (1993) and Grilo \& Thurik (2008) argue that other factors beyond the economic ones play a role in shaping entrepreneurship. Shane (1993) found a strong influence of Hofstede's (1980) cultural value of uncertainty avoidance on the levels of innovativeness of societies. Morris et al. (1994) focused on the variable of individualism, which is related both to the desire of people to violate norms and to incentives for achievement (Hofstede 1980), which are characteristics associated with entrepreneurship. Wildeman et al. (1999) examined the effects of Hofstede's (1980) cultural variables of power distance and uncertainty avoidance on entrepreneurship and showed that they positively influence levels of self-employment.

In general, we may approach the relationship between cultural values and entrepreneurial activity from two different perspectives. These are the supply or "pull" perspectives and the demand or "push" perspectives. On the supply side, we have the "legitimation of entrepreneurship" and the "aggregate psychological traits", and on the demand side, we have the "dissatisfaction perspective" for business start-ups and entrepreneurship in general (Stanworth and Curran, 1973; Verheul et al., 2002; Thurik et al., 2008; Wennekers et al., 2008). The predicted relationship between the "push" and "pull" perspectives is the opposite (Hofstede et al., 2004; Wennekers et al., 2008).

The "legitimation of entrepreneurship", or the "legitimation" or "moral approval" of entrepreneurship, focuses on the impact of the norms and institutions on society at large (Etzioni, 1987). The cultural determinants of entrepreneurship may also include "aggregate psychological traits", as more entrepreneurial values in a society can lead to an increase in the number of people displaying entrepreneurial behaviour (Davidsson, 1995, 2004). A third 
explanation for entrepreneurship is what is called the "dissatisfaction perspective", which, at the macro level, assumes that differences in values between the population as a whole and potential entrepreneurs form the basis for variation in entrepreneurship. Baum et al. (1993) concluded that countries with a high degree of uncertainty are associated with higher rates of self-employment, explaining that the cultural determinants of entrepreneurship as the "push explanation for entrepreneurship". Nooerderhaven et al. (2004), who used a sample of 22 OECD countries and described the countries with a low degree of uncertainty as "entrepreneurial economies", had the same conclusion. They concluded that per capita GDP has a strong, negative effect on the rate of business ownership in nine countries characterised by high uncertainty avoidance and no effect in countries with low uncertainty avoidance. On the level of business ownership, Wennekers et al. (2008) examined the influence of cultural attitudes towards uncertainty avoidance. They identified a strong, positive effect of uncertainty avoidance on business ownership, concluding that high levels of uncertainty avoidance push people into entrepreneurship through self-employment (in line with Baum's hypothesis).

The model of cultural values formed in the two groups of countries is roughly the following: Southern countries accept more widely the existence of greater inequalities and (according to Hofstede) demonstrate higher rates of uncertainty, when compared to Northern European countries. Individual achievements are not highly appreciated and at the same time the socially established organization rules and practices are not acceptable. Nevertheless, individuals express pride, faith, and cohesion with their families and any specific social group they belong to. Feminine values, such as quality of life, care for the weak, and solidarity play a small part and are characteristic features of Northern European countries. Accordingly, the values of imposition and of dispute do not seem to prevail. Regarding the cultural indicators there is a clear distinction between the two groups of countries. Southern countries have a lower ranking, implying lower uncertainty avoidance levels. The Southern countries examined here are characterized by limited future orientation, lack of scheduling and long-term planning and portray low efficiency and human orientation levels while their main focus is on short-term planning.

\begin{tabular}{|c|c|c|c|c|c|c|c|c|c|}
\hline & 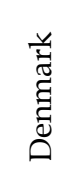 & $\begin{array}{l}\overparen{\Xi} \\
\stackrel{\Xi}{\Xi} \\
\stackrel{\Xi}{\Xi}\end{array}$ & 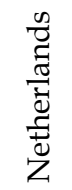 & 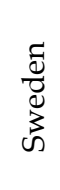 & 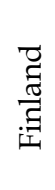 & $\begin{array}{l}\mathscr{U} \\
\mathbb{U} \\
\tilde{U}\end{array}$ & $\begin{array}{l}\text { đే } \\
\text { की }\end{array}$ & $\frac{\vec{\pi}}{ \pm}$ & 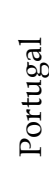 \\
\hline Performance Orientation & 4.22 & 4.36 & 4.32 & 3.7 & 3.8 & 3.2 & 4.01 & 3.58 & 3.6 \\
\hline Future Orientation & 4.44 & 3.98 & 4.61 & 4.4 & 4.2 & 3.4 & 3.51 & 3.25 & 3.7 \\
\hline Gender Egalitarianism & 3.93 & 3.21 & 3.5 & 3.8 & 3.4 & 3.5 & 3.01 & 3.24 & 3.7 \\
\hline Assertiveness & 3.8 & 3.92 & 4.32 & 3.4 & 3.8 & 4.6 & 4.42 & 4.07 & 3.7 \\
\hline Institutional Collectivism & 4.8 & 4.63 & 4.46 & 5.2 & 4.6 & 3.3 & 3.85 & 3.68 & 3.9 \\
\hline In-group Collectivism & 3.53 & 5.14 & 3.7 & 3.7 & 4.1 & 5.3 & 5.45 & 4.94 & 5.5 \\
\hline Power Distance & 3.89 & 5.15 & 4.11 & 4.9 & 4.9 & 5.4 & 5.52 & 5.43 & 5.4 \\
\hline Human Orientation & 4.44 & 4.96 & 3.86 & 4.1 & 4 & 3.3 & 3.32 & 3.63 & 3.9 \\
\hline Uncertainty Avoidance & 5.22 & 4.3 & 4.7 & 5.3 & 5 & 3.4 & 3.97 & 3.79 & 3.9 \\
\hline
\end{tabular}

Source: House et al. (2004), (The data were collected in the period 1995 - 1997).

Table 5. The cultural dimensions 
Based on the definitions of the variables used to express cultural background by House et al. (2004), we can assume that societies with high values for performance orientation should be associated with higher levels of entrepreneurship, given that they promote profit and performance improvement in their economies. Such societies value training, development, assertiveness, competitiveness, individual achievement and taking initiative, and entrepreneurship contributes towards these goals. High values for future orientation should be related to increases in entrepreneurship too. Indeed, such societies tend to achieve economic success, have flexible and adaptive organisations and managers, and favour financial prosperity, which can facilitate new businesses. Furthermore, a decrease in genderbased differences should reflect greater entrepreneurship because more women will have the chance to exercise their entrepreneurial skills. Such societies tend to afford women a greater role in community decision-making and have a higher percentage of women participating in the labour force and in positions of authority. Moreover, it is expected that a positive correlation exists between higher values of assertiveness and entrepreneurship given that aggression and austerity drive global competitiveness. Such societies value success, progress and competition and tend to act and think of others as opportunistic. Generally, collective activity in a society (institutional collectivism) should be positively related to entrepreneurship, as group loyalty is encouraged even if individual goals suffer. In contrast, in-group collectivism is expected to be associated with lower levels of entrepreneurship because, in essence, in-group collectivism is incompatible with competitiveness and the development of free entrepreneurship: it favours conceptualism and small, low-risk businesses. High levels of power distance indicate that economic development occurs only for those who (mainly) have economic power in societies. Consequently, it is expected to have a negative correlation with opportunity entrepreneurship. In such societies, only a few people have access to resources, skills and capabilities. Human orientation is expected to have a positive correlation with entrepreneurship because, in societies with a high level of human orientation and that have the primary aim being profits; the government's focus should be on individuals. There is expected to be a negative correlation, as it was said before, between uncertainty avoidance and entrepreneurship because lower levels of uncertainty avoidance have been repeatedly associated with higher levels of economic activity (Swierczek \& Ha, 2003; Hofstede et al., 2008). Such societies tend to be less calculating when taking risks and show less resistance to change.

\section{Education system, research and academic entrepreneurship}

The education system and academic research lead to research results that can contribute to the growth of academic entrepreneurship through the creation of spin off companies.

\subsection{Education system and research}

The question raised is under what conditions different educational systems generate different performance levels in scientific research. We shall attempt a comprehensive analysis of the education system and the way in which it promotes the growth of research. Stressing the importance of the transformation of research results to research activity, we examine to what extent the growth of knowledge in the university and research community is transformed in research results (publications). We thus examine to what extent the education system (structure, motivation) provides satisfactory research results. 
E.U. countries allocate on average $11 \%$ of their total public expenditure to education. North European countries (Sweden, Ireland, and Denmark) rank at the highest positions with an average of $15 \%$. Table 6 presents the total public expenditure on education as a percentage on GDP, showing the increased expenditure for education by North European countries. Mediterranean countries have almost the same percentage as to GDP compared to that of the EU-27 (5.07\%). Overall, in the EU, 22\% of total educational expenditure regards higher education.

\begin{tabular}{|l|c|c|c|c|}
\hline & \multicolumn{2}{|c|}{$\begin{array}{c}\text { Expenditure on tertiary } \\
\text { education (\% of total } \\
\text { expenditure on education) }\end{array}$} & \multicolumn{2}{c|}{$\begin{array}{c}\text { Expenditure for all levels of } \\
\text { education (\% of GDP) }\end{array}$} \\
\hline Country & 2001 & 2008 & 2001 & 2008 \\
\hline Denmark & 32 & 28 & 8,44 & 7,75 \\
\hline Ireland & 29 & 23 & 4,27 & 5,62 \\
\hline Netherlands & 27 & 28 & 5,06 & 5,46 \\
\hline Sweden & 28 & 27 & 7,12 & 6,74 \\
\hline Finland & 33 & 31 & 6,04 & 6,13 \\
\hline Greece & 31 & - & 3,5 & - \\
\hline Spain & 23 & 23 & 4,23 & 4,62 \\
\hline Italy & 16 & 18 & 4,86 & 4,58 \\
\hline Portugal & 18 & 19 & 5,61 & 4,89 \\
\hline EU -27 & 22 & 22 & 4,99 & 5,07 \\
\hline
\end{tabular}

Source: Eurostat.

Table 6. Total public expenditure on education

The field of studies, as shown in Table 7, does not seem to be an inhibitor for research that may be commercialized. In particular it does not seem that there are significant differences between the weighted average of the number of graduates per educational field of Southern and Northern European countries. The only significant differentiation observed, refers to the predominance of fields of health and care in North countries $(21 \%)$ in comparison to Southern countries $(16 \%)$.

In 2009, seventeen EU members marked an increasing or stable trend in R\&D expenditure, while in 2010 sixteen EU members forecast an increase of said index in relation to GDP. However, provisional data show that there has been a decrease in 2010 in most EU countries and the same trend seems to be mantained during 2011.

In Europe, almost 1 million students graduate annually from higher education and approximately 100,000 receive a PhD title, while indicatively in the USA the number of the latter is almost half. However, taking into consideration GDP, the USA invests 2.5 times more money in education in comparison to the EU. As expenditure per postgraduate or PhD student in Europe is smaller that in the US, the EU focuses more on quantity rather that quality, thus risking to fail the expectations of the entrepreneurial sector (European Commission, 2011). In Europe, 71\% of the investment in R\&D is made by its four bigger members (Germany, France, United Kingdom, and Italy). The 29\% collected by all other members almost corresponds to the percentage held by Germany alone. The higher 
percentage of investments on R\&D per country is implemented by the private sector, with North European countries ranking a higher rate in comparison to the Mediterranean. In the public sector, the image is reversed, as only $28 \%$ of investments in R\&D correspond to North European countries and $49 \%$ to the Mediterranean.

\begin{tabular}{|c|c|c|c|c|c|c|c|c|c|c|}
\hline &  &  & 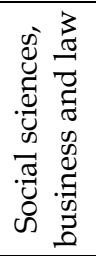 &  & 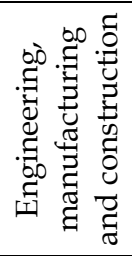 & 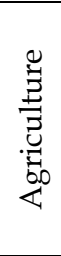 & 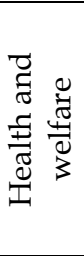 & 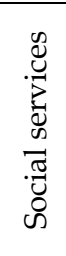 & $\frac{\mathscr{d}}{\stackrel{0}{0}}$ & 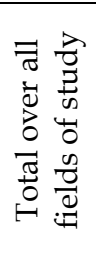 \\
\hline $\begin{array}{l}\text { Northern } \\
\text { European } \\
\text { countries }\end{array}$ & $13 \%$ & $11 \%$ & $31 \%$ & $8 \%$ & $12 \%$ & $1 \%$ & $21 \%$ & $5 \%$ & $4 \%$ & $100 \%$ \\
\hline $\begin{array}{l}\text { Southern } \\
\text { European } \\
\text { countries }\end{array}$ & $10 \%$ & $12 \%$ & $31 \%$ & $9 \%$ & $15 \%$ & $2 \%$ & $16 \%$ & $2 \%$ & $4 \%$ & $100 \%$ \\
\hline
\end{tabular}

Source: OECD, Education at a Glance 2011.

Table 7. Weighted average of the number of graduates per educational field for South and North European countries (data 2009)

Furthermore South countries have traditionally (2000-2009) lower participation rates for gross domestic expenditure in research and technological development (R\&D) both in comparison to the EU total and to the average of North European countries.

During the period 1995-2008, the total investment of the EU in R\&D in real prices increased by $50 \%$. During the period 2000-2007, the tension of the R\&D index remained stable as a result of the parallel increase of GDP and GERD (Gross Expenditure on R\&D). During the 2007-2009 period, the index was increased as a GDP rate (from $1.85 \%$ to $2.01 \%$ ) due to the GDP decrease and the priority given to $R \& D$, financially and by private investments to R\&D. This can be attributed to the positive impact of the Treaty of Lisbon and of the national reforms implemented since 2005 (European Commission, 2011).

Table 8 clearly shows that Southern countries lag in absolute terms in comparison to North European countries in the sector of investment expenditures on research and technological development, particularly in the private sector.

The capacity to produce effective basic research may be illustrated by the number if scientific publications presented by each country. Specifically, the US ranks at the highest position compared to the other OECD countries, producing $28 \%$ of all scientific publications, which has dropped in the last six years. The same course has been followed by the EU, which ranks immediately after the USA. On the contrary, China's rates have doubled during the same period (UNESCO, 2010). 12\% of scientific publications correspond to the EU when the average of all countries is $10 \%$. The United Kingdom, Germany, France, and Italy rank at the highest position and indeed are equally high in comparison to other countries globally. 


\begin{tabular}{|c|c|c|c|}
\hline & $\begin{array}{c}\text { Private Sector - } € R \& D \\
\text { per resident }(2009)\end{array}$ & $\begin{array}{c}\text { Public Sector - } € \text { R\&D } \\
\text { per resident (2009) }\end{array}$ & $\begin{array}{c}\% \text { GDP total } \\
\text { R\&D } \\
(2009)\end{array}$ \\
\hline Denmark & 814.2 & 35 & 3.02 \\
\hline Netherlands & 306.1 & 80.4 & 1.84 \\
\hline Sweden & 802.6 & 50.5 & 3.62 \\
\hline Finland & 910 & 115.9 & 3.96 \\
\hline Greece* $^{*}$ & 31.6 & 25.1 & 0.58 \\
\hline Spain & 165.1 & 63.9 & 1.38 \\
\hline Italy & 165.3 & 44.6 & 1.27 \\
\hline Portugal & 122.6 & 19.3 & 1.66 \\
\hline Average & 414.7 & 54.3 & 2.2 \\
\hline
\end{tabular}

Source: Eurostat.

Note: *Available data 2007.

Table 8. Expenditure of the private and the public sector per resident and \% on GDP on the R\&D expenditure

The relevant index shows that the lowest position is held by Ireland and Portugal. In this case the developed countries of Northern Europe do not predominate in total. Moreover, we observe a significant increase of publications, of over $100 \%$, in Portugal, Ireland and Greece.

\begin{tabular}{|l|c|c|c|}
\hline \multirow{2}{*}{ Country } & \multicolumn{2}{|c|}{$\begin{array}{c}\text { Scientific } \\
\text { publications }\end{array}$} & $\begin{array}{c}\text { Change } \\
(\%)\end{array}$ \\
\cline { 2 - 3 } & 2000 & 2008 & \\
\hline Denmark & 8,896 & 13,260 & 49 \\
\hline Finland & 8,358 & 12,606 & 51 \\
\hline Ireland & 3,178 & 7,799 & 145 \\
\hline Netherlands & 22,181 & 35,425 & 60 \\
\hline Sweden & 17,409 & 22,976 & 32 \\
\hline Greece & 5,924 & 13,855 & 134 \\
\hline Italy & 38,708 & 63,408 & 64 \\
\hline Portugal & 3,804 & 10,781 & 183 \\
\hline Spain & 27,089 & 52,664 & 94 \\
\hline
\end{tabular}

Source: European Commission, 2011.

Table 9. Number of scientific publications per million of population (data 2008)

Moreover, research activities differ significantly per university unit and scientific field. Comparison of research activity of universities shows that each university publicizes almost 250 articles referring to social studies and more than 5,100 articles on sciences (Audretsch, 2006).

Figure 2 depicts the relation between the expenditure for $R \& D$ and the number of publications per one million of population. 


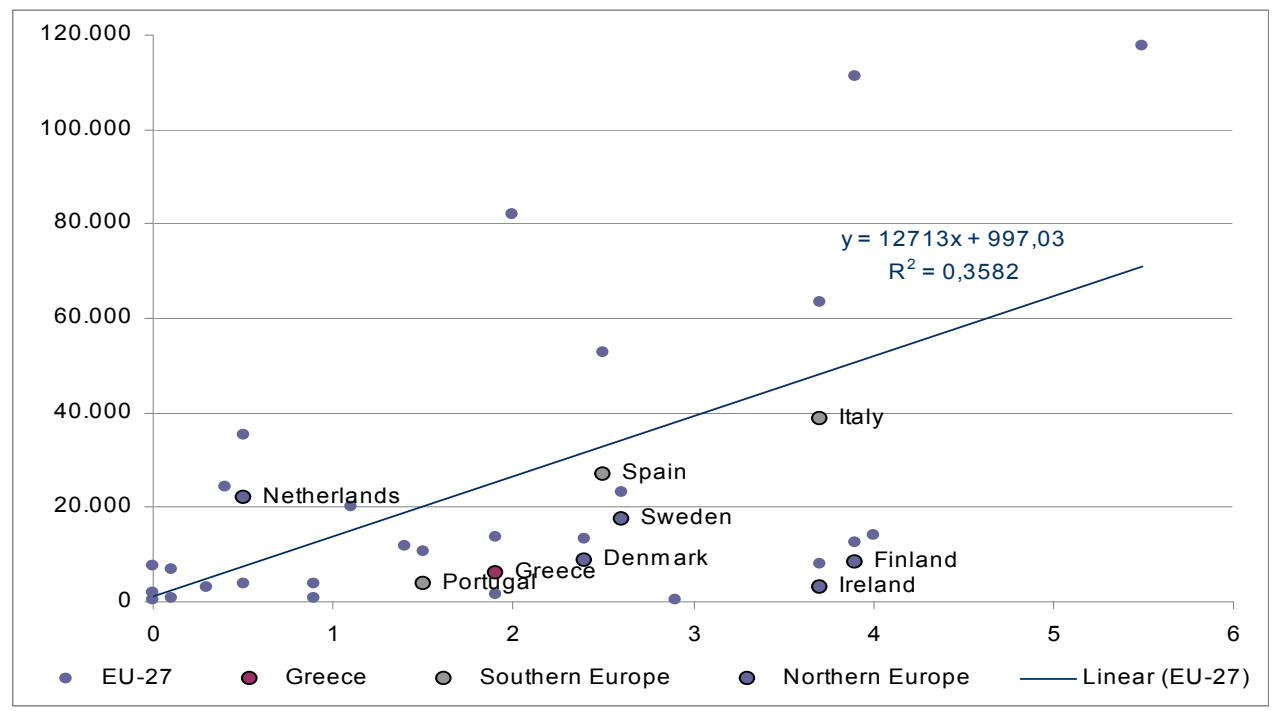

Sources: R\&D: Eurostat, Publications: Innovation Union Competitiveness Report, European Commission, 2011

Fig. 2. Relation between expenditure for $\mathrm{R} \& \mathrm{D}^{1}$ (vertical axis) and the number of publications per million of population (horizontal axis)

Figure 2 demonstrates the positive relationship between the two sizes. We conclude that countries that spend larger sums to invest in $R \& D$ have a higher proportion in the number of publications per million population.

\subsection{Research activity and results}

This unit aims to examine to what extent research results (publications) offer substantial added value. Added value is measured by citations and by register patents. In this process, a definitive role is played by the existing funding status of university research in order to promote entrepreneurial activity (Audretsch, 2007) and by the quantity of the research results produced. In essence, in this part we will analyze the relation between publications, citations and registered patents. Namely how different research systems "produce" different usable results (citations).

Patenting and copyrights help academic institutions by protecting them from the competition created by the availability of their intellectual property (Scott, 2004). It has been found that the number of publications does not affect the creation of spin-off companies (Landry et al., 2006) and that patents are not the key factors for the prediction of the number of publications, but are positively linked to citations (Agrawal \& Henderson, 2002).

1 R\&D is calculated as a rate on GDP. To find the relation between this index and the publications data of 2008 were used for scientific publications and data of 2007 for R\&D, as we assume that the expenditure for R\&D brings results in the next year. 
Through patenting, there is an increase in the interaction between scientists, who are active in the academic or industrial sector and in this way, the traditional scientific standards are enhanced. Moreover, if researchers are excluded from patents, then the technology dissemination mechanism will be characterised by ineffectiveness (Strandburg, 2005).

Table 10 depicts the number of registered patents per one million of population. Portugal, Greece and Spain rank in the lowest positions, a fact that is an indication that research results (publications) do not offer direct added value also presenting a smaller number of registered patents.

\begin{tabular}{|l|c|c|c|c|c|}
\hline & 1985 & 1990 & 1995 & 2000 & 2005 \\
\hline Denmark & 15.94 & 24.04 & 35.22 & 43.21 & 42.24 \\
\hline Ireland & 4.92 & 7.57 & 7.94 & 12.22 & 15.01 \\
\hline Netherlands & 38.03 & 39.03 & 48.09 & 67.67 & 66.96 \\
\hline Sweden & 51.06 & 50.82 & 83.57 & 77.24 & 80.85 \\
\hline Finland & 11.28 & 30.01 & 60.77 & 67.26 & 53.03 \\
\hline Greece & 0.15 & 0.45 & 0.16 & 0.69 & 1.00 \\
\hline Spain & 0.89 & 1.83 & 2.02 & 3.48 & 4.55 \\
\hline Italy & 8.98 & 11.32 & 10.65 & 11.63 & 12.44 \\
\hline Portugal & 0.15 & 0.07 & 0.32 & 0.38 & 1.07 \\
\hline
\end{tabular}

Source: OECD, Science Technology and Industry Scoreboard, 2007 edition, IMF World Economic Outlook database (last update April 2009), data process.

Table 10. Number of registered patents per one million of population

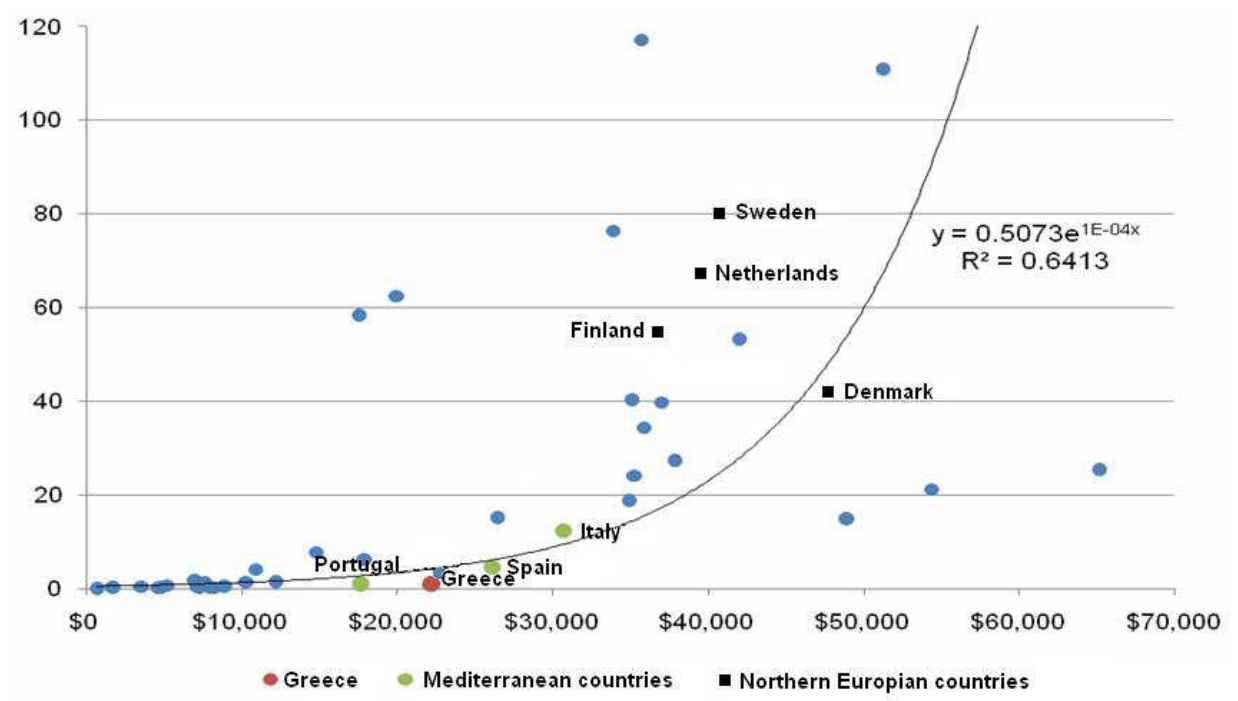

Source: OECD, Science Technology and Industry Scoreboard, 2007 edition, IMF World Economic Outlook database (last update April 2009), data process.

Fig. 3. Relation between GDP per capita (horizontal axis) and number of patents per one million of population 
Table 10 shows a clearly higher number of registered patents by countries of Northern Europe as to patents registering. It is indicative that these countries show particularly satisfactory research results on an international scale, as they exceed the respective dynamic of the USA (which in 2005 presented almost 53 patents per one million of population), but are clearly behind Japan (more than 110 patents per one million of population in 2005).

Figure 3 depicts the relation between the domestic product per capita and the amount of expenditure for $R \& D$. The number of patents registered shows the potential of production of applied research activity results.

The production of basic research does not refer so much to the quantity of publications, but mainly to their quality. Therefore, for a more thorough analysis, we shall examine the relevant significance of scientific work, as resulting from the number of references (citations) they receive from other scientific works. Table 11 shows the index of the relevant "distinction" of scientific works of each country.

\begin{tabular}{|l|l|}
\hline Denmark & 0.94 \\
\hline Ireland & 0.76 \\
\hline Netherlands & 0.97 \\
\hline Sweden & 0.86 \\
\hline Finland & 0.83 \\
\hline Greece & 0.47 \\
\hline Italy & 0.70 \\
\hline Spain & 0.60 \\
\hline Portugal & 0.51 \\
\hline
\end{tabular}

Source: OECD, Science Technology and Industry Scoreboard, 2007.

Table 11. "Distinction" index of scientific works of each country²

As to distinct and recognized scientific publications North European countries present the highest "distinction" index (but for Ireland).

\section{Academic spin offs and entrepreneurship}

An academic spin off company is established in order to commercially exploit an intellectual property produced within the framework of the academic community. Usually patents, copyrights and the appropriate legitimation mechanisms are created to protect spin off companies (Scott, 2004). Universities create secondary technological results that become the object of exploitation by new businesses (Shane, 2001a, 2001b). In other words, academic spin offs are the externalities commercialised by businesses for which the university is the source of dissemination and for which it is not fully compensated (Harris, 2001). Spin off companies are the commercial aspect of scientific research, although studies on their establishment, the conditions of growth and comparative analysis between countries are scarce, particularly in the EU. Usually these concern case studies (Rabinow, 1997; Tuunainen, 2005) based on qualitative methods.

2 The index is shaped as a percentage of each country's scientific works that receive references (citations) in relation to the total of scientific works, without taking into consideration same country references (Data refer to publications in sciences and technological sciences for 2003). 
The issue of the production of basic applied research in Universities, of the transfer of the knowledge produced in Universities to the private sector and its effective commercialization, is an issue of concern for the academic community and scholars in recent years. Until the 1980's, mainly in the USA, the issue had been resolved based on the limiting version, namely the limitation of Universities to basic research (Hofstadter, 1995) and the promotion of "open science" (Argyres et al., 1998). "Open science" includes the acceptance of findings based on the impartiality of researchers, their systematic scepticism, and the minimization of copyright (communism of knowledge) (Meron, 1993). Thus the activity of Universities referring to teaching, research, publication and public service or transfer activity, does not have the nature of commercialised relations.

Moreover, there has been an effort to determine the reasons that some academic institutes exploit their intellectual property more in comparison to others. Basic reasons why this situation is shaped may be the availability of venture capital in universities, the commercial orientation of the university community, the intellectual superiority and the policy followed by the university community. Specifically in 101 universities in the world (530 spin off start ups), it was found that the factors associated with the quality of human resources as well as the ability of the university in finding funding sources increase the creation of new businesses (Gregorio \& Shane, 2003). Finally, universities well established in the research sector present a larger number of spin off companies in comparison to "younger" universities that are characterised as less flexible in the process of taking business initiative (venture) (Franklin et al., 2001). After data accumulation by 47 academic spin off companies of the 8 greater Universities of Belgium, it seems that the policies implemented in academic institutes affect the growth potential of such businesses (Degroof \& Edward, 2004).

The establishment of a spin off company is not necessarily implemented when its founder leaves the academic institute or graduates. It may need some years and this is because it is necessary that he/she acquire more skills or because there is the need to find partners. However, this process may be accelerated if its founder has direct access to the university unit, which will offer them - even informally - support for the transfer of knowledge and technology (Müller, 2008).

The moment of registering of a patent or license issuance for the exploitation of an invention is early and its commercial success from its immediate exploitation cannot be secured. Usually further improvement is needed as well as market data analysis (Jensen \& Thursby, 2001). Besides, it has been found that it is not only the creation, but also the development process of this kind of businesses that play a significant role (Vohora et al., 2004). Indeed the participation of a member from the entrepreneurial world is deemed necessary as it will form the connecting link between science and market and will contribute to the minimization of the time between the registration of an idea and its commercial exploitation.

It is particularly interesting to examine the classification of academic spin offs that operate in academic entrepreneurship: a) technology scouts: post-doctorate researchers who have excellent knowledge of technology but do not have adequate entrepreneurial knowledge, b) teams led by an experience professor who is in contact with public authorities, c) "forefront" teams who develop in high paces as they do have the necessary entrepreneurial cognitive background, d) teams offering support and consulting at the process of drafting the 
proposal for funding and finally, e) teams that include a network of external partners (banks, business funds investors, business partners) (Sassmannshausen, 2011).

Libecap (2007) classified academic spin offs based on the kind of start-up policy: a) absence of start-up policy, b) minimum selectiveness/support, c) medium selectiveness/support, and d) full selectiveness/ support. It has been proven that the latter case is the best form which can exploit entrepreneurial opportunities with a high growth potential. However it is clarified that the latter form may be characterized as ideal but it is not directly feasible due to limited resources.

Using the Robert \& Malone (1996) model of support and selectiveness, it seems that if a University follows a low support/ low selectiveness policy (many spin offs with little support) and it is an academic institute that already has entrepreneurial activity, it has greater potential for entrepreneurial growth (e.g. MIT). On the contrary, a high support/ high selectiveness policy (few spin offs with great and orderly support for the University) is more appropriate for underdeveloped -as to entrepreneurial environment- universities (e.g. Yale). In this way, different approaches to technology transfer and commercialization may lead to similar positive effects for the local economy.

In a business, the separation and selection among many ideas, information and proposals is a difficult process. The process is made even more difficult when it refers to an academic unit that produces knowledge on its own. Thus, as important it is for a business to develop mechanisms in the framework of entrepreneurship, it is equally important for an academic spin off. This position is enhanced as academic institutes do not operate as "business of business" but as "business of education" despite the entrepreneurial nature that they often may demonstrate. When the only commercial mechanisms they have are patents and licenses, the academic staff must develop their entrepreneurial skills and the knowledge "filter". Besides, the majority of academic staff has limited experience in the entrepreneurial sector, ideas are sometimes vague, they use academic terminology and address an unknown market (Audretsch, 2007).

Differentiating the process of knowledge dissemination depending of the type of science it can be seen that the process is more implicit and less encoded in social sciences. On the contrary, in sciences the process is less implicit and more encoded, with expanded geographic proximity (Audretsch et al., 2006).

It has been noted that there are also differences between the motives given to researchers of various countries. Specifically in a survey held in Sweden it was noted that the motives for the commercialization of academic research results are different from those in USA. In the USA, the copyright of academic results belongs to academic units, while in Sweden it belongs to the researcher. Furthermore, in Sweden, academic institutes are funded by the state while in the USA mainly by the private sector ${ }^{3}$.

A corresponding survey held in academic spin offs in Finland showed that there is not a significant interaction between them and the academic institutes. The total of spin-offs under examination concerned small enterprises, unable to invest in research and development. Moreover, such enterprises do not need direct R\&D inputs as they have the

\footnotetext{
${ }^{3}$ Commercialization of Academic Research Results Författare , D. Nordfors et. Al, VINNOVA Forum Innovation Policy in Focus VFI 2003:1, 2003.
} 
know-how when established. It is also very likely that they seek for partners in other scientific fields ${ }^{4}$.

However, the fear of technological backwardness for the economy of the USA in the 1980's led to the introduction of three basic instruments (Lee, 1996): The Bayh Dole Act (1980) that allowed Universities to licence the Federally financed R\&D results to business, the Cooperative Research Act (1986) that allowed Universities and enterprises to organise technology-transfer alliances without undue fear of antitrust litigation and the Stevenson Wedler Act (1986) to foster the exchange of scientific and technical personnel among universities, industry, and federal laboratories. The introduction of such instruments in the same time with the highlighting of the importance of the biotechnology sector in the relations between Universities and industries (Argyres et al., 1998; Hayton et al., 2002) created a new situation in the relations between Universities and industries throughout the 80 's and the 90 's at least in the USA, which however affected the relevant thinking internationally (European Commission, 1995).

Thus, in EU countries institutional changes are developed, such as the Business Innovation Centres (Fahey, 1997), the Industrial Liaison offices and similar legislative alterations are introduced to key economies. The role of the latter is particularly expanded in countries such as Sweden and Ireland and include the finding of funding, sponsorship, network development, etc. (Klofstenn \& Jones-Evans, 1999).

The new perception of University relations, the so-called "neotransferism" (Lee, 1996), creates the conditions for a second revolution (the first referred to the integration of research in academic operation, apart from teaching). This perception includes the economic and social growth as part of the mission of academic institutes (Etzkowitz, 1998). The University technology transfer to industry those days can take four dimensions: a) industry - sponsored contact research, b) consulting, c) technology licensing, and d) technology development and commercialization (Shane, 2002). Each University, in the framework of national legislation in which it operates, chooses to enhance less or more one or more of the above dimensions. However, there is a remarkable difference among them. The two first could be deemed as of a nature that drastically limits the outflow of knowledge (the first one excludes it) while the third and fourth lead to an outflow at the cost of an induced inflow either to the University per se or to society.

In the last 20 years, many Universities across the world (mainly in the USA and in Europe) boost the development of spin off companies. The 90's, with the magnification of the role of economy of knowledge and the rise of capital markets, magnified the significance of spin offs as a method of knowledge transfer from universities to enterprises. This process was particularly beneficial for the financial state of Universities. In 1996 the sale of equity in spin off companies by U.S. Universities totalled $\$ 25,3$ mil (Bray \& Lee, 2000). In the same decade, it was found that this methodology was more effective that that of technology transfer through licensing. In 1996, the average annual income from a traditional licence was $\$ 63.832$ while the average value of equity sold was $\$ 691.121$ (10 times more than the average annual income from a traditional license). Well known examples of spin offs include companies

4 Production of Knowledge Revisited: The Impact of Academic Spin-Offs on Public Research Performance in Europe (PROKNOW), Coordinator: Social Science Research Center Berlin (WZB) Research Group Science Policy Studies, Andreas Knie and Dagmar Simon, 2008. 
such as Hewlett Packard from Stanford, Tracer from the University of Texas, Digital Equipment from MIT, etc.

The establishment of spin off companies by academic institutes is implemented at a slow pace outside the USA. In most OECD countries besides USA, 25 spin off companies maximum are created each year whose size, revenue and products production is of small, while only a small percentage of those belongs to high tech category. Indeed most of them come from top Universities of the world while the supporting structures are costly (Callan, 2001).

Spin offs contribute to national competitiveness, to the creation of jobs on a national level, while in the same time they ensure inflow to the academic community. The types of spin offs and the growth stages may differ (Wright et al., 2008). A study conducted on 109 spin off companies of Cambridge University (years of establishment 1979 - 2002) of which 18\% were consulting companies, $34 \%$ technological, $21 \%$ products production and the remaining software development companies, showed that different types of spin offs have different needs and require different treatment by the state (Druilhe \& Garnsey, 2004).

Table 12 verifies the fact that more spin off companies are established in the USA. Specifically for the 1980-2003 period 4,543 spin offs were established in total and in 2004 alone 462 were created. Furthermore during the same period the revenue from their operation was increased from $\$ 200$ millions to $\$ 1,3$ billions (Wright et al., 2007). In the EU a survey held on 172 university institutes from 17 countries, proved that 103 of them had spin off companies while only $50 \%$ of them established at least one spin off in 2004 (European Commission, 2005). Sweden and Germany ranked at very high positions as to the number of spin off companies, while the Netherlands ranked lower.

\begin{tabular}{|l|c|c|}
\hline Country & Period & Number of spin-offs \\
\hline France & $1984-2005$ & $1230^{*}$ \\
\hline Netherlands & $1980-1990$ & $300^{*}$ \\
\hline United Kingdom & $1981-2003$ & $1650^{*}$ \\
\hline Belgium & $1980-2005$ & $320^{*}$ \\
\hline USA & $1980-2003$ & $4543^{*}$ \\
\hline Italy & $2000-2008$ & $372^{* *}$ \\
\hline Spain & $2001-2005$ & $380^{* *}$ \\
\hline
\end{tabular}

Sources: * Wright et al., 2007, ** OECD, 2003

Table 12. Number of university spin-off companies

However, the pace is different in the European South compared to the European North. A survey held by the Association of Spanish OTRIS 5 in Spain notes that 380 academic spin-offs were created up to 2005. Before 2001, this number counted only 18 spin-offs, therefore almost all academic spin-offs in Spain were created after 2001. One of Italy's greatest problems is the small number of researchers in universities, public research centers and, more specifically, in businesses. Specifically in Italy, from 2000 up to 2008, 372 spin offs were created in total. The upward trend is observed from 2003 onwards culminating in 2004 (65 spin offs) (Iacobucci et al., 2011). The number of spin offs that are active in Greece is almost 10.

${ }^{5}$ Manual for supporting the creation of spin-offs, BIC Minho - Oficina da Inovação, S.A., 2009. 


\section{Conclusion}

Activation of academic entrepreneurship is a phenomenon dealt at the two more mature phases of development of economic systems (efficiency driven and innovation driven) with an emphasis on the latter phase where further development of the growth depends on the commercialisation of new products of knowledge. Comprehension of all of the above conditions leads to the conclusion that the USA, compared to Europe, is characterised by an environment that is more favourable to academic entrepreneurship and that the European North is characterised by a more favourable environment in comparison to the European South.

\begin{tabular}{|l|l|l|}
\hline & European North & European South \\
\hline Entrepreneurial Opportunities & Superiority & Hysteresis \\
\hline Transaction Costs & Lower & Higher \\
\hline Uncertainty & Lower & Higher \\
\hline $\begin{array}{l}\text { Social Capital } \\
\text { Trust }\end{array}$ & High & Low \\
\hline Scientific Networks & Satisfactory & Satisfactory \\
\hline Property rights & High consolidation & Low consolidation \\
\hline Cultural Background & Favourable & Unfavourable \\
\hline Education System & High public expenditure & Lower public expenditure \\
\hline Research Private Funding & High & Low \\
\hline Scientific Publications per resident & High & High \\
\hline $\begin{array}{l}\text { Patents Number per one million of } \\
\text { population }\end{array}$ & High & Very Low \\
\hline Publications Distinction Index & High & Low \\
\hline Number of Spin Offs & Estimation) higher & (Estimation) lower \\
\hline
\end{tabular}

Table 13. Academic entrepreneurship in the European North and the European South

Entrepreneurial activity exploiting the conditions of asymmetrical information has the ability to identify new academic entrepreneurial opportunities. However, this presupposes an institutional (cultural and regulatory) framework that will reward and encourage this process. Certainly, the members of the academic community face the moral hazard of either concealing or exploiting the entrepreneurial opportunity, or of abandoning the main duty of research and knowledge dissemination.

Growth conditions of academic entrepreneurship are affected by the burden of the transaction costs which has as crucial feature the uncertainty and the burden of operation of the entrepreneurial activity.

The growth of social capital, of trust and of academic networks can have a positive effect on academic entrepreneurship. The manner in which property rights originating from research are produced and registered is equally important.

Naturally, the way in which property rights on the production of university innovation are recognized and registered is important. The brave move implemented in the USA by which the property of the innovation was transferred from the sponsors to the producers, played a 
key role in the growth of the role of academic entrepreneurship in the growth of entrepreneurship and growth in the USA after 1990.

Simultaneously, the cultural environment affects the growth of academic entrepreneurship on two levels: on the level or researchers and potential entrepreneurs and on the level of university administrations which also carry the viewpoints of society. Thus if a society has cultural characteristics that do not favor the growth of entrepreneurship (like the European South for instance) then there is no reason for us to believe that part of the society (such as the university community) will feel otherwise no matter how the existence of a higher educational level may differentiate the separate characteristics of the academic environment. On the other hand the effect will be graver on the way that university administrations deal with academic entrepreneurship. A negative entrepreneurial atmosphere in society is certainly creating a negative "welcome" atmosphere of academic entrepreneurial opportunities on the side of University administrations.

Analyzing the relations between the academic system and research we discover the North countries have higher funding rate towards education system mainly through private funding. Despite this fact scientific publications in the North and the South are comparable, while the number of patents is much higher in the European North. The same also applies on publications distinction indexes. Namely in essence we realize that while scientific results are produced in the South, in the North they take a registered form (e.g. in the form of patents). This may means that the direction of scientific research in the South is not offered for further financial exploitation e.g. humanities, basic research not linked to commercial potential, etc. Finally, it all comes down to a low level of academic activity in the European South in comparison to the European North.

The limited academic entrepreneurship of the South has a complex interpretational background, which is disseminated in all aspects of social and economic activity of an economy. This image also characterizes the hardships faced by economies in their transition to a growth stage based on innovation.

Future research may investigate the relation between university entrepreneurship and other factors (such as the cultural background of the societies), testing for the direction for the causality. Furthermore, the analysis of the relation between entrepreneurship, university research, and economic growth and the suggestion of certain policy measures to exploit university entrepreneurship, could be realised comparing other group of countries, or a group of countries as a whole.

\section{References}

Acemoglu, D., Johnson, S., \& Robinson JA. (2004). Institutions as the Fundamental Cause of Long-Run Growth, CEPR Discuss. Pap. 4458

Acemoglu, D., Johnson S. (2005). Unbundling Institutions. Journal of Political Economy, No. 113, (5), pp. 949-995

Agrawal, A., \& Henderson, R. (2002). Putting Patents in Context: Exploring Knowledge Transfer from MIT. Management Science, Vol. 48, No. 1, (January 2002), pp. 44-60

Aldrich, E., Fiol, M. (1994). Fools rush in? The institutional context of industry creation. Academy of Management Review, Vol. 19, No. 4, pp. 645 - 670 
Anton, J., Yao, D. (1994). Expropriation and inventions: Appropriable rents in the absence of property rights. American Economic Review, Vol. 84, pp. 190-209

Argyres P.C., Dimopoulos, S., March-Russell, J. (1998). Black Holes and Sub-millimeter Dimensions, Physics Letter, Vol. 441, No. 1-4, p.96-104

Arora, A. (1996). Contracting for tacit knowledge: The provision of technical Services in technology licensing contracts. Journal of Development Economics, Vol. 50, pp 233-256

Audretsch, D. B., Keilbach, M. C., Lehmann, E.E. (2006). Entrepreneurship and Economic Growth, Oxford University Press, New York

Audretsch, D., Lehmann, E. (2005). Mansfield's missing link: The impact of knowledge spillovers on firm growth. Journal of Technology Transfer, Vol. 30, pp. 207-210

Audretsch, D., (2007). The Entrepreneurial Society. Oxford University Press, ISBN 978-0-19518350-4, New York

Banal-Estañol, A., Macho-Stadler, I. (2007). Commercial Incentives in Academia, UAB working paper

Baum, J.R., Oian J.D., Erez, M., Schnel,1 E.R., Smith, K.G., Sims, H.P. (1993). Nationality and work role interactions: a cultural contrast of Israeli and US entrepreneurs' versus managers' needs. J of Bus Ventur, Vol. 8, No. 6, pp. 499-512

Bekkers, R., Gilsing, V., Van der Steen, M. (2006). Determining Factors of the Effectiveness of IP-Based Spinoffs: Comparing the Netherlands and the US. Journal of Technology Transfer, Vol. 31,No. 5, pp. 545-566

Bergh, J., Stagl, S. (2003). Coevolution of economic behaviour and institutions: towards a theory of institutional change. J of Evol Econ, Vol. 13, No. 3, pp. 289-317

Bourdieu, P. (1986). The Forms of Capital in Richardson, Handbook of Theory and Research for the Sociology of Education, Greenwood Press, New York

Bray, M. J., Lee J. N. (2000). University revenues from technology transfer: Licensing fees vs. equity positions, Journal of Business Venturing, Vol. 15. No. 5-6, pp. 385-392

Breznitz, S., O'Shea, R., Allen, T. (2008). University Commercialization Strategies in the Development of Regional Bioclusters. J PROD Innovation Management, Vol. 25, pp. 129-142

Elco van Burg, A., Romme G., Gilsing V., Isabelle M. M., Reymen, J. (2008). Creating University Spin-Offs: A Science-Based Design Perspective Product Development \& Management Association. J prod innov manag, Vol. 25, pp. 114-128

Burt, R. S. (1992). Structural Holes: The Social Structure of Competition, Harvard University Press

Callan, B. (2001). Generating spin-offs: evidence from the OECD. Science Technology Industry Review, Special issue on fostering high tech spin-offs: a public strategy for innovation, Vol. 26, pp. 13-56

Cassia, L., Colombelli, A. (2008). Do universities knowledge spillovers impact on new firm's growth? Empirical evidence from UK, Springer Science and Business Media, LLC

Chakrabarti, A. (2003). Role of Universities in the Product Development Process: Strategic Considerations for the Telecommunications Industry. Special Working Paper Series on Local Innovation Systems. Boston: Massachusetts Institute of Technology

Cox, M. (2003). When trust matters: explaining difference in voter turnout. Journal of Common Market Studies, Vol. 41, No. 9, pp. 757-770 
Davidsson, P. (1995). Culture, structure and regional levels of entrepreneurship. Entrepreneurship and Regional Dev, Vol. 7, pp. 41-62

Davidsson, P. (2004). Researching entrepreneurship, international studies in entrepreneurship, Springer, New York

Davidsson, P., Wiklund, J. (1997). Values, beliefs and regional variations in new firm formation rates. J of Econ Psychol, Vol. 18, pp.179-199

Degroof, J., Edward, B.R. (2004). Overcoming weak entrepreneurial infrastructures for academic spin-off ventures. MIT IPC, Working Paper IPC-04-005, April 2004

Druilhe, C., Garnsey, E. (2004). Do Academic Spin-Outs Differ and Does it Matter? Journal of Technology Transfer, Vol. 29, pp. 269-285

Easterly, W., Ritzen, J., Woolcock, M. (2006). Social cohesion, institutions, and growth. Econ and Polit, Vol. 18, No. 2, pp. 103-120

Elfring, T., Hulsink, W. (2003). Networks in entrepreneurship: The case of high-technology firms. Small Business Economics, Vol. 21, pp. 409-422

Etzioni, A. (1987). Entrepreneurship, adaptation and legitimation. J of Econ Behav and Organ, Vol. 8, pp. 175-189

Etzkowitz, H. (1998). The Norms of Entrepreneurial Science: Cognitive Effects of the New University-Industry Linkage. Research Policy, Vol. 27, pp. 823-833

European Commission. (2005). Green Paper on Innovation

European Commission. (2011). Innovation Union Competitiveness Report, Research and innovation

Fahey, D.C.C. (1997). European Business Innovation Centres as Regional Innovation Systems. Proceedings of the regional studies association conference, Frankfurt (Oder) September 20th-23rd

Fiet, O. (1996). The informational basis for entrepreneurial discovery. Small Business Economics, Vol. 8, pp. 419-430

Franklin, S., Wright, M., \& Locket, A. (2001). Academic and surrogate entrepreneurs in university spin out companies. Journal of Technology Transfer, Vol. 26, No. 1-2, pp. 127-141

Gabbay, S., Leenders, R. (1999). Corporate Social, Capital and Liability. Kluwer, New York

Georgas, J., Berry, J.W., (1995). An ecocultural taxonomy for cross cultural psychology, Journal of Cross-Cultural Research, Vol. 29, pp. 121-157

Granovetter, S. (1985). Economic action and social structure: The problem of embeddedness. Amer. J. Soc., Vol. 91. No.3, pp. 481-510, Green Paper on Innovation, European Commission, 1995

Gregorio. Di., Shane, D. (2003). Why do some universities generate more start-ups than others? Research Policy, Vol. 32, pp. 209-227

Grilo, I., Thurik, A.R., (2008). Determinants of entrepreneurial engagement levels in Europe and US. Ind and Corp Chang, Vol. 17, No. 6, pp.113-1145

Harris, R. (2001). The Knowledge Based Economy: Intellectual Origins and New Economic Perspectives. International, International Journal of Management Reviews, Vol. 3, No.1

Hayton, J.C., George, G., Zahra, S.A. (2002). National culture and entrepreneurship: a review of behavioural research. Entrepreneurship Theory and Pract, Vol. 26, No.4, pp. 33-52 
Herbig, P., Dunphy, S. (1998). Culture and Innovation in Cross Cultural Management. An International Journal, Vol. 5, No.4, pp. 13-21

Hofstadter, D., (1995). Fluid Concepts \& Creative Analogies: Computer Models of the Fundamental Mechanisms of Thought, together with the Fluid Analogies Research Group. Basic Books, New York

Hofstede, G., (1980). Culture's Consequences: International differences in Work-related Values. CA: Sage Publ., Beverly Hills

Hofstede, G., (2001). Culture's Consequences: Comparing Values, Behaviors, Institutions, and Organizations across Nations (2 ed.). Sage Publications. London

Hofstede, G.J., Jonker, C.M., Verwaart, T., (2008). Modeling Culture in Trade: Uncertainty Avoidance. Proceedings of 2008 Agent-Directed Simulation Symposium (ADS'08), SCS, San Diego

Hofstede, G., Noorderhaven, N.G., Thurik, A.R., Uhlaner, L.M., Wennekers, A.R.M., Wilderman, R.E., (2004). Culture's role in entrepreneurship: self- employment out of dissatisfaction. Edward Elgar. Cheltenham

Hong, Y., (2009). A dynamic constructivist approach to culture: Moving from describing culture to explaining culture. In: Understanding Culture: Theory, research and application, Wyer, R.S., Chiu, C.Y., Hong, Y.Y., Psychol press

House, R.J., Hanges, P.J., Javidan, M., Dorfman, P.W., Gupta, V., (2004), Culture, Leadership and Organisations - The GLOBE study of 62 societies. Sage Publ, Thousand Oaks, CA

Huson, M., MacKinnon, G., (2003). Corporate Spinoffs and Information Asymmetry Between Investors, Journal of Corporate Finance, Vol. 9, No.4

Iacobucci, D., Iacopini, A., Micozzi, A., Orsin, S. (2011). Academic entrepreneurship and regional growth. Evidence from Italian spin-offs, Proceedings of Technology Transfer Conference 2011, Augsburg

Jensen, R., Thursby, M. (2001). Proofs and Prototypes for Sale: The Licensing of University Inventions. American Economic Review, Vol. 91, pp. 240 - 259

Jones-Evans, D., Klofsten, M. (1999). Creating a bridge between university and industry in small European countries: The role of the Industrial Liaison Office, $R \mathcal{E} D$ Management 29, Vol. 47, No. 1

Kirzner, I. (1973). Competition and Entrepreneurship. Chicago University Press, Chicago, IL. ISBN 0226437752

Landry, R., Amara, N., Rherrad, I. (2006). Why are some university researchers more likely to create spin-offs than others? Evidence from Canadian universities. Research Policy. Vol. 35, No. 10, December 2006, pp. 1599-1615

Lee, C., Lee, K., Pennings, J., (2001). Internal Capabilities, External Networks and performance: A Study on Technology Based Ventures, Strategic Management Journal, Vol. 22, pp. 615-640

Lee, Y., (1996). "Technology transfer" and the research university: a search for the boundaries of university industry collaboration", Research Policy, Vol. 25, No. 6, 843-863

Libecap, G., (2007). University Entrepreneurship and technology transfer: Process, Design and Intellectual Property, Emerald Group Publishing Limited, ISBN: 978-0-76-231230-6, UK 
Lieberman, M.B., Montgomery, D.B. (1988). First-mover advantages. Strategic Management Journal, Vol.9, Special Issue: Strategy Content Research (Summer, 1988), pp. 41-58

Lowe, R.A. (2002). Entrepreneurship and Information Asymmetry: Theory and Evidence from the University of California. Carnegie Mellon University, mimeo

Lynn, R. (1991). The secret of the miracle economy: different national attitudes to competitiveness and money. The Social Affairs Unit, London

Macho-Stadler, I., Perez-Castrillo, D., Veugelers, R. (2008). Designing contracts for University Spin-offs, Journal of Economics E Management Strategy, Vol. 17, No.1, pp. 185-218

McClelland, D.C. (1961). The Achieving Society. Van Nostrand, New Jersey

Meron, T. (1993). Henry's Wars and Shakespeare's Laws: Perspectives on the Law of War in the Later Middle Ages, Oxford University Press, New York

Morris, M.H., Davis, D.L., Allen, J.W. (1994). Fostering corporate entrepreneurship: Cross cultural comparisons of the importance of individualism versus collectivism. J of Int BusStud, Vol. 25, No. 1, pp. 65-89

Müller, K. (2008). Academic Spin-Off's Transfer Speed - Analyzing the Time from Leaving, University to Venture. DRUID, Working Paper No. 08-07

Mustar, P. (1997). Spin-off enterprises. How French academics create high-tech companies: The conditions for success or failure, Science Public Policy, Vol. 24, pp. 37-43

Nerkar, A., Shane, S. (2003). When do start-ups that exploit patented academic knowledge survive? International Journal of Industrial Organization, Vol. 21, No. 9, pp. 13911410

Nicolaou, N., Birley, S. (2003a). Academic networks in a trichotomous categorisation of university spinouts, Journal of Business Venturing, Vol. 18, pp. 333-359

Nicolaou, N., Birley, S. (2003b). Social Networks in Organizational Emergence: The University Spinout Phenomenon the Entrepreneurship Centre, Management Science, Vol. 49, No. 12, pp. 1702-1725

Noorderhaven, N.R., Thurik, A.R., Wennekers, S., van Stel, A. (2004). The role of diassatisfaction and per capita income in explaining self-employment across 15 European countries, Entrep. Theory and Pr. Vol. 28, No.5, pp.447-466

North, D.C. (1981). Structure and Change in Economic History. WW Norton \& Company, New York

North, D.C. (1990). Institutions, Institutional Change and Economic Performance, Cambridge University Press, Cambridge

OECD. (2000). Science, Technology and Industry Outlook

OECD. (2003). Turning science into business. Paris, France

OECD. (2011). Science, Technology And Industry Scoreboard

Oyserman, D., Sorensen, N. (2009). Understanding cultural syndrome effects on what and how we think: A situated cognition model., In Understanding Culture: Theory, research and application, Wyer, R.S., Chiu, C.Y., Hong, Y..Y, pp 25-52, Psychology press

Pisano, G. (1989). Using equity participation to support exchange: Evidence from the biotechnology industry. Journal of Law, Econon. Organ. Vol. 5, No.1, pp 109-126 
Pollock, T.G., Rindova, V.P. (2003). Media legitimation effects in the market for initial public offerings, Academy of Management Journal, Vol. 46, pp. 631-642

Porter, M. (2002). Global Competetivness Report, World Economic Forum, Geneva Switzerland

Portes, A. (1998). Social Capital: Its Origins and Applications in Modern Sociology. Annu. Rev. of Sociol. Vol 24, pp 1-25

Proton. (2005). Proton Europe Annual Survey: Financial Year 2004, published by the European Commission

Putnam, R. (1995). Bowling Alone: America's Declining Social Capital, Journal of Democr, Vol 6, pp 65-78

Rabinow, P. (1997). Making PCR: A story of biotechnology, University of Chicago Press

Ring, S., Van de Ven, H. (1994). Developmental Processes of Cooperative Interorganizational Relationships. Academy of Management Review, Vol. 19, No.1, pp. 90-118

Roberts, E.B., Malone, D.E. (1996). Policies and Structures for Spinning off New Companies from Research and Development Organizations. RED Management, Vol. 26, pp. 1748

Rodrik, D., Subramanian, A., Trebbi, F. (2004). Institutions Rule: The Primacy of Institutions over Geography and Integration in Economic Development, Journal of Economic Growth, Vol. 9, pp. 131-65.

Rosenberg, N., Birdzell, L.E. (1986). How theWest Grew Rich: The Economic Transformation of the Industrial World, New York, Basic Books

Sassmannshausen, S.P. (2011). Entrepreneurial Technology Scouting: Encouraging Academic Spin-offs by Utilizing the Theory of Individual-Opportunity Nexus, (submission to Journal of Enterprising Culture), forthcoming

Savig, L., Schwartz, S.H. (2007). Cultural Values in organisations: insights for Europe, Eur J of Int Manag, Vol. 1, No.3, pp. 176-190

Scholten, V. (2006). The early growth of academic spin offs, Thesis Wageningen University and research Centrum, The Netherlands

Schumpeter, J. (1934). The Theory of Economic Development. Cambridge, Massachusetts: Harvard University Press

Scott, S. (2004). Academic entrepreneurship: University spinoffs and wealth creation, Edward Elgar, Williston, Vermont

Shane, S. (1993). Cultural influences on national rates of innovation. J of Bus Ventur, Vol. 8, pp. $59-73$

Shane, S. (2001b). Technology Regimes and New Firm Formation, Management Science, Vol. 47, pp. 1173-1190

Shane, S. (2001a). Technological Opportunities and New Firm Creation. Management Science, Vol. 47, pp. 205-220

Shane, S. (2002). Organizational endowments and the performance of university start-ups. Management Science, Vol. 48, No.1, pp. 154-170

Shane, S. (2004). Academic entrepreneurship: University spinoffs and wealth creation. Cheltenham, UK and Northampton, MA: Elgar

Shane, S., Stuart, T. (2002). Organizational endowments and the performance of university start-ups. Management Science, Vol. 48, No. 1, 154-170 
Shane, S., Venkataraman, S. (2000). The Promise of Entrepreneurship as a Field of Research, Academy of management Review, Vol. 25, No. 1, pp. 217-226

Singh, P., Hills, E., Hybels, C., Lumpkin, T. (1999). Opportunity recognition through social network characteristics of entrepreneurs. Frontiers of Entrepreneurship Research. Babson College, Wellesley, MA.

Stanworth, M.J.K., Curran, J. (1973). Management motivation in the smaller business, Gower Press, London

Strandburg, K. (2005). Curiosity-Driven Research and University Technology Transfer, New York University School of Law, Advances In The Study Of Entrepreneurship, Innovation And Economic Growth, Vol. 16, pp. 97-126.

Swierczek, F.W., Ha, T.T. (2003). Entrepreneurial Orientation, Uncertainty Avoidance and Firm Performance, Entrep and Innov, Vol. 4, No. 1, pp. 46-58

Thomas, A.S., Meller, S.L. (2000). A case for comparative entrepreneurship: assessing the relevance of culture, J of Int Bus Stud, Vol. 31, pp. 287-301

Thurik, A.R., Carree, M.A., Van Stel, A.J., Audretsch, D.B. (2008). Does self-employment reduse unemployment? J of Bus Vertur Vol. 23, No. 6, 673-686

Tuunainen, J. (2005). Contesting a hybrid firm at a traditional university. Social Studies of Science, Vol. 35, No. 2, pp. 173-210

UNESCO. (2010). Science Report, UNESCO Publishing

Verheul, I., Wennekers, A.R.M., Audretsch, D.B., Thurik, A.R. (2002). An eclectic theory of entrepreneurship. In Entrepreneurship: determinants and policy in a European-US comparison, Audretsch, D.B., Thurik, A.R., Verheul, I., Wennekers, A.R.M. pp. 11-81, Boston, MA, Kluwer

Vohora, A., Wright, M., Lockett, A. (2004). Critical Junctures in the Development of University High-Tech Spinout Companies, Research Policy, Vol. 33, No. 1, pp. 147175

Weber, M. (1930). The Protestant Ethic and the Spirit of Capitalism, Unwin Hyman, London

Weick, K.E. (1979). The social psychology of organizing, MA: Addison-Wesley, Reading

Wennekers, S. (2005). Entrepreneurship at country level: Economic and non-economic determinants, Scales Research Reports 200602, EIM Business and Policy Research

Wennekers, S., Thurik, A.R., Van Stel, A.J., Noorderhaven, N. (2008). Uncertainty avoidance and the rate of business ownership across 21 OECD countries, 1976-2004, J of Evol Econ, Vol. 17, No. 2, pp.133-160

Wennekers, A.R.M., Uhlaner, L., Thurik, A.R. (2002). Entrepreneurship and its conditions: a macro perspective, Int J of Entrep Educ, Vol. I, No. 1, pp.25-64

Wildeman, R.E., Hofstede, G., Noorderhaven, N.G., Thurik, A.R., Verhoeven, W.H.J. (1999). Self-employment in 23 OECD countries; the role of cultural and economic factors, Research Report 9811/E, Zoetermeer: EIM Small Business Research and Consultancy

Wright, M., Clarysse, B., Lockett, A., Knockaert, M. (2008). Mid-range universities' linkages with industry: Knowledge types and the role of intermediaries, Research Policy, Vol. 37, No.8, pp. 1205-1223 
Wright, M., Clarysse, B., Mustar, P., Lockett, A., (2007). Academic Entrepreneurship in Europe, Edward Elgar Publishing, UK 


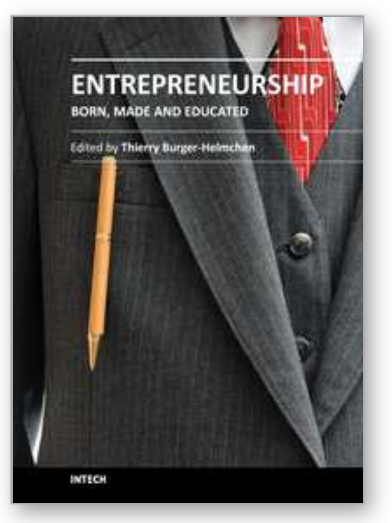

\author{
Entrepreneurship - Born, Made and Educated \\ Edited by Prof. Thierry Burger-Helmchen
}

ISBN 978-953-51-0210-6

Hard cover, 336 pages

Publisher InTech

Published online 14, March, 2012

Published in print edition March, 2012

Entrepreneurship has a tremendous impact on the economic development of a country. As can be expected, many public policies foster the development of self- entrepreneurship in times of unemployment, praise the creation of firms and con- sider the willingness to start new ventures as a sign of good fortune. Are those behaviours inherent to a human being, to his genetic code, his psychology or can students, younger children or even adults be taught to become entrepreneurs? What should be the position of universities, of policy makers and how much does it matter for a country? This book presents several articles, following different research approaches to answer those difficult questions. The researchers explore in particular the psychology of entrepreneurship, the role of academia and the macroeconomic impact of entrepreneurship.

\title{
How to reference
}

In order to correctly reference this scholarly work, feel free to copy and paste the following:

Panagiotis E. Petrakis (2012). Entrepreneurship, University Research, and Growth: European North vs. South, Entrepreneurship - Born, Made and Educated, Prof. Thierry Burger-Helmchen (Ed.), ISBN: 978-953-51-02106, InTech, Available from: http://www.intechopen.com/books/entrepreneurship-born-made-andeducated/entrepreneurship-university-research-and-growth-european-north-vs-south

\section{INTECH}

open science | open minds

\section{InTech Europe}

University Campus STeP Ri

Slavka Krautzeka 83/A

51000 Rijeka, Croatia

Phone: +385 (51) 770447

Fax: +385 (51) 686166

www.intechopen.com

\section{InTech China}

Unit 405, Office Block, Hotel Equatorial Shanghai

No.65, Yan An Road (West), Shanghai, 200040, China

中国上海市延安西路65号上海国际贵都大饭店办公楼 405 单元

Phone: +86-21-62489820

Fax: +86-21-62489821 
(C) 2012 The Author(s). Licensee IntechOpen. This is an open access article distributed under the terms of the Creative Commons Attribution 3.0 License, which permits unrestricted use, distribution, and reproduction in any medium, provided the original work is properly cited. 